\title{
DEMOCRATIC CITIZENSHIP BETWEEN THE MODERN STRATEGY OF LEARNING AND ANCIENT EXPERIENCE
}

\author{
Dario Saftich, BA \\ EDIT Rijeka \\ e-mail: dario.saftich@ri.htnet.hr
}

\begin{abstract}
A b stract
Education for democratic citizenship, within the conditions of democracy, should occupy a more decisive role in the school system. Modern strategies of learning and teaching should not exclude ancient experiences and roots. In democratic conditions, which retain ties to the ancient ones, oratory is an important factor of political life. This is precisely why the art of speaking can be relocated to the centre of attention. The importance of political speech, in the broadest sense of the word, is identical to that in Greek citystates. The teachings of Aristotle and Quintilian show how nothing has changed significantly during the last century and the millennium, at least when we speak of the human spirit and man's most basic skill. It is therefore possible to draw ties between education for the democratic citizenship and rhetoric, in the positive sense. Basic democratic values and tolerance can be best developed through discussion and persuasion, and not through simply learning the formal foundations of a democratic organisation. In this work we will depict that the strategy of learning, in terms of democratic citizenship and history, which are tightly bound, is in fact the strategy of selection, just as it is in the case of oratory education.
\end{abstract}

Key words: strategy, education, democracy, democratic citizenship, oratory skill, ancient experience, rhetoric, selection, history, tolerance

\section{Introduction}

The democratic system allows all its full-fledged members of society to participate in management, one which should aim at a common well-being as well as protect the rights of all people. It is obvious that an inclusion in decision making tied to one's own society brings a series of responsibilities. This is why it is necessary to acquire knowledge and skill for an active participation and promotion of human rights and civil responsibilities. Young people are generally characterized by an aversion toward being actively engaged in society's development, and they therefore present a great challenge for the entire educational system. It is because of this that human rights and democratic society organizations are assuming a more important role in the school system's development. The term "democratic citizenship" is actually a synonym for another often used notion within the bounds of social sciences: democratic political culture. In ancient Greece, citizenship was viewed as a political role not based on a certain territory, or a certain ethnicity, but on the active participation in the political life of a community. We could say that the difference between citizens in modern 
democratic societies and subjects lies not in ownership of rights - because almost all legal citizens possess rights - but in the readiness and capability to immerse themselves in a critical reassessment of political power and a willingness to discuss public issues. As early as ancient times, in the sophists' era, the power of efficient speech was realized, i.e. the possibility and ability to influence an auditorium and that instrument's importance in the scope of public life, especially in politics and justice. Political speech in the most general sense of the notion is equal in importance today as it was in the Greek city-states. In today's conditions of democracy, which are tied to the ancient ones, the skill of speech, or rhetoric, can be reasserted as something central and can become an important factor of social, as well as political life in a positive sense. At this point we must adopt the term "rhetoric". Rhetoric came to be in ancient Greece, in one of the philosophical schools, with the intent of teaching its attendants to correctly present their thoughts, argument their claims and discredit those of their opponents. Although also popular in Rome, the fall of that empire and the entrance of Europe into the dark Middle Ages caused it to become slowly forgotten. And today? In today's era of capitalism, when the main goal is to sell a product as well as possible (or an idea, a political program, or present one's knowledge) it has become evident that the seller is in fact selling himself. Since most business and selling is done through verbal communication, rhetoric has once again (justifiably) found its place under the sun. Modern strategies of learning and teaching should not forget ancient experiences and roots, still present today, especially in Anglo-Saxon schools. Acquaintance with democratic principles, social institutions and rules, as well as history should not be boiled down to learning abundant facts, but should serve as motivation for the development of discussion and independent thought and speech. Democracy and rhetoric in the positive sense can and should be placed together, as early as possible in the classroom.

\section{Democratic Citizenship}

Education in human rights and democratic citizenship was systematically introduced into the Croatian educational system in 1999 by the Croatian government. This education corresponds to the application of the National Program of Education for Human Rights and Democratic Citizenship. The program includes education on human rights, education for democratic citizenship, identities and intercultural education, education for peace and nonviolent resolution of conflict, education for sustainable development, education for the prevention of prejudices and discrimination, researching humanitarian law, and similar. Education in human rights and democratic citizenship enables the application of some active methods of learning and teaching: project learning, cooperative learning, learning in pairs, role playing, simulations, problem solving, social learning using information and communication technology and others. Political history has shown us that democracy cannot function without a democrat: democratic institutions and institutes are not enough in order for democracy to fully thrive; there has to be a democratic political culture which is capable of supporting this democracy. At an individual level, this means that there must be citizens present who possess the knowledge, abilities and attitudes necessary for an active, informed and active participation in the political process. Just as the understanding of citizenship as a status is tied to Roman tradition, the perception of citizenship as a role is tied to ancient Greek tradition, where citizenship was viewed as a political role not based on one certain territory or ethnicity, but on the active participation in the political life of a 
community. Democratic citizens, or democrats, are not born but are created through socialization processes. The main factors of a political socialization are most often listed as family, groups of friends, mass media, civil society and the educational system. One could say that the educational politics of a society are actually a group of decisions about how to utilize the educational system in order to secure a vision of an appealing society in the future. In any case, besides schools and other factors, family also plays and important role in the upbringing and education; this was known even in ancient times. In parents I should wish that there should be as much learning as possible. Nor do I speak, indeed, merely of fathers; emphasizes Quintilian, who proves his modernity through this statement. (Quintilian, 1985, 45). He continues: Of paedagogi this further may be said, that they should either be men of acknowledged learning, which I should wish to be the first object, or that they should be conscious of their want of learning (Quintilian, 1985, 46). In other words, the educated society applies to slaves, as well. Even more so today, when there shouldn't be any more "slaves", or intellectual enslavement through manipulation of public opinion and democratic discourse.

\section{Rhetoric}

The basic purpose of oratory schooling is evident in the very title; it is filling the gap that regular school programs allow in oratory skills and verbal expression in general. The conception of oratory finds its support in ancient schools in which rhetoric was nurtured. Modern and elite American colleges also provide an example. This is normal, as oratory education is not intended for one type of school, but equally serves social, humanistic, natural and technical branches. The first goal of oratory education is to provide students with a vast amount of direction in order to offer them an initial skill in speaking. Through this, they will become increasingly more capable of expressing their thoughts and more powerful in their affection of others through speech. In an environment of democratic competition, in which speech is a deciding medium, oratory power is a first-class condition for acquiring a high and prestigious role in society.

To speak clearly means to think clearly, to speak of novelty means to think of novelty. Learning about good speech to a great extent means learning about good thought. Speech consists of both sending and receiving speech. Apart from simple speech, the skill of listening to speech is also important, and so advancing this skill is also a goal to aim for. The only way to speak interestingly is to speak of something the listener is unfamiliar with, and the only way to prove something true is to have facts at one's disposal. And so, oratory serves to motivate a quick and systematic acquisition of knowledge. Oratory is speaking to others, the listeners. It is effective if the speaker is concentrated on the listeners, just as they are. This is why oratory teaches us methods of how to apprise the people we are communicating as realistically as possible, something that may come of use in real life generally.

In rhetoric, debate is valued as a superior skill, and something which should be afforded special attention. If we look at how real speech came to be in ancient Greece, and observe its modern presentation, we will see that nothing, in fact, has changed. In place of the amphitheatre, there appears the presentation hall, in place of noted papyrus PowerPoint presentations or bullet points on A6 format paper. Rhetoric can help us with presentation, to 
curb stage fright, leave an impression of an individual who understands what he is presenting (because even a prodigy in his field will leave a wrong impression if he is unable to present himself correctly, if he gives in to nerves and fear) and finally, intrigue an audience into sharing our interests.

\section{Ancient Experience}

Today, even in the era of developed democracy, an ancient approach to oratory can still be of tremendous help. During the Roman republic, oratory was valued almost as much as during the Golden Age of Athens. In the time of Greek military and economic decline, but when Greece was still able to culturally "patronize" Rome, there were generations of speakers active in Rome, representing the best meld of both Greek and Roman tradition. The most known of these personalities was undoubtedly Marcus Tullius Cicero. His speech Institutio Oratoria, or rather of the greatest questions in regards to it, was dedicated to the celebrated Roman speakers of the generation prior to his own. In his opinion, this was the last generation able to enjoy the non-tainted democratic spirit and open culture of the Roman Republic, prior to the agony of a republican government and the civil wars which would lead to the founding of an empire. Cicero believes that this generation of speakers represented the best of both the Greek and Roman oratory traditions and was a prime example of Roman moral and honour. Learning about good speech generally comes down to learning about good thought, but also about the importance of justness and honour. Oratory and the basic values of democracy and democratic citizenship greatly overlap. Thus, one of the basic goals of developing oratory skill is developing a correct and creative line of thought. Let the orator I propose to form, claims Marcus Fabius Quintilian, be $a$ good man skilled in speaking. But the requisite which Cato has placed first in this definition-that an orator should be a good man-is naturally of more estimation and importance than the other. It is important that an orator should be good because, should the power of speaking be a support to evil, nothing would be more pernicious than eloquence alike to public concerns and private. I myself, who, as far as is in my power, strive to contribute something to the faculty of the orator, should deserve very ill of the world, since I should furnish arms, not for soldiers, but for robbers. (Quintilian, 1985, 490). My judgment carries me still further, for I not only say that he who would answer my idea of an orator must be a good man, but that no man, unless he be good, can ever be an orator. (Quintilian, 1985, 491). It is evident to all that a principal part of oratory consists in discoursing on justice and virtue. But will the unjust man and the vicious treat of such subjects with the respect that is due to them? (Quintilian, 1985, 492).

Dishonest simulation however guarded, always betrays itself, nor was there ever such power of eloquence in any man that he would not falter and hesitate whenever his words were at variance with his thoughts. But a bad man must of necessity utter words at variance with his thoughts, while good men, on the contrary, will never be lacking a virtuous sincerity of language nor (for good men will also be wise) a power of producing the most excellent thoughts, which, though they may be destitute of showy charms, will be sufficiently adorned by their own natural qualities, since whatever is said with honest feeling will also be said with eloquence. (Quintilian, 1985, 496). 
Since a speaker is a good man, and a good man cannot be conceived to exist without virtuous inclinations, and virtue, though it receives certain impulses from nature, requires notwithstanding to be brought to maturity by instruction, the orator must above all things study morality and must obtain a thorough knowledge of all that is just and honourable, without which no one can either be a good man or an able speaker. (Quintilian, 1985, 500). In that sense, a speaker must peruse with the most diligent application the authors that give instruction in virtue. (Quintilian, 1985, 501). The speaker also needs knowledge of the civil law and of the manners and religion of that state, whatever it be, over which he shall endeavour to exert any influence. (Quintilian, 1985, 506). Even today, these guidelines have not lost a bit of their correctness. Only that some words might be better translated into the politically correct speech of the present, although the call for morality shouldn't be any less important in modern civilization than it was two millennia ago.

\section{The Usefulness of Rhetoric}

The connection between oratory and political culture was also observed by Aristotle. From this assumption, Aristotle emphasizes, stems the belief that rhetoric is a branch of dialectics and philosophical research which can rightfully be called politics: The political orator aims at establishing the expediency or the harmfulness of a proposed course of action; if he urges its acceptance, he does so on the ground that it will do good; if he urges its rejection, he does so on the ground that it will do harm; and all other points, such as whether the proposal is just or unjust, honourable or dishonourable. (Aristotle, 1989, 15). In that sense, Aristotle is also modern when he states that political orators often make any concession short of admitting that they are recommending their hearers to take an inexpedient course or not to take an expedient one. The question whether it is not unjust for a city to enslave its innocent neighbours often does not trouble them at all. (Aristotle, 1989, 15). First, then, concludes Aristotle, we must ascertain what are the kinds of things, good or bad, about which the political orator offers counsel. For he does not deal with all things, but only with such as may or may not take place. (Aristotle, 1989, 17).

Although he was the chief of democracy, Socrates unfortunately didn't understand the importance of studying rhetoric. In the midst of his debate with the rhetoric teacher Gorgias, Socrates says: Come, then, and let us see what we really mean about rhetoric; for I do not know what my own meaning is as yet. When the assembly meets to elect a physician or a shipwright or any other craftsman, will the rhetorician be taken into counsel? (Plato, 1968, 86-87). At first glance Socrates' remarks seem rational, but Gorgias doesn't lack counterarguments: I like your way of leading us on, Socrates, and I will endeavour to reveal to you the whole nature of rhetoric. You must have heard, I think, that the docks and the walls of the Athenians and the plan of the harbour were devised in accordance with the counsels, partly of Themistocles, and partly of Pericles, and not at the suggestion of the builders. (Plato, 1968, 87).

Aristotle firmly rejected Socrates' theories on the uselessness of rhetoric: Rhetoric is useful because things that are true and things that are just have a natural tendency to prevail over their opposites. (Aristotle, 1989, 4). There is no dilemma, then, in regards to the usefulness of rhetoric, something evident in the function of truth, and not trickery. Aristotle proves his modernity in regards to oratory skill when he indirectly acknowledges 
that the scientist must be able to present his discoveries and achievements to the masses in a simple, comprehensible manner. Therefore, according to Aristotle's theory, rhetoric is the ability to extract the believable in any given case. As for modes of persuasion achieved through speech, there are three kinds: The first kind depends on the personal character of the speaker; the second on putting the audience into a certain frame of mind; the third on the proof, or apparent proof, provided by the words of the speech itself.. (Aristotle, 1989, 7). According to Aristotle, he who is capable of mastering modes of persuasion is also capable of logical judgment and realization of character through thought.

Cicero's words, inspired by Greek theories and examples, can serve as a roadmap for speakers even today: Oratory is much greater than most people assume it to be, and much more complicated than most skills and sciences... all emotions afforded to the human race by nature must be deeply studied, because the entire sense and strength of speech should be presented in order for the listener's souls to become either calmed or excited. (Cicero, 2002, 37).

\section{Selection of Information}

People learn with their hearts, heads and hands, therefore through thought, experience and action. In order for a person to adopt a certain model, theory, knowledge, he must first be allowed to make it his property; it must become «his». For this to occur, in addition to a receptive listening of wise words, a personal interaction must be present. I must be able to subjectively see that which is presented to me: as a (active, thoughtful, emotional, adult) subject. This adoption is difficult if there is no offer of thought, exchange and testing or if the speaker imagines himself in the ownership of the final truths. (Winkler and Commichau, 2008, 158).

One should also take into consideration that facts always stem from a selective interpretation of facts, which means that, in addition to those verbalized facts, there are many left unsaid. (Žitinski-Šoljić, 2001, 8). Without selective interpretation, we wouldn't be able to finish any one of our reports. Through selection we transcend our own immersion in the present moment, and carry out analysis and interpretation with the help of principles as the primary elements independent of that «now». (Žitinski-Šoljić, 2001, 8). In other words, we could endlessly describe all that happened, presenting all we have seen. (Žitinski-Šoljić, $2001,8)$. The goal, however, is to achieve quality, arrive at the correct conclusion at the correct time. If we try to answer the question of what reality is and how we may reproduce it, we see that we can only do this if we make a choice. But without reason, the choice doesn't exist. We make a moral decision about something we know to be good, while we create opinions on things we are unfamiliar with. Goodness and malice are completely in our ownership, because if we are capable of doing something good then we are capable of doing something bad. (Žitinski-Šoljić, 2001, 9).

We communicate by offering a relevant choice, and not a presentation of the facts. If we were to offer a mere presentation of the facts, we would repeat history, and would be incapable of making worthy judgments. And they do not stem from facts, but from principle. (Žitinski-Šoljić, 2001, 11). Originality in speaking consists of finding a new viewpoint or an unexpected way of viewing a problem. (Winkler and Commichau, 2008, 
150). As such, rhetoric becomes a discipline which explores a special specificity, that which in each independent case becomes a good argument. (Winkler and Commichau, 2008, 151).

\section{History}

The culmination of the Roman school system was the study of rhetoric. For his school, Quintilian devised a special program, which included preliminary written exercises ending with declamations, theoretical classes in rhetoric and reading of approved pages from the works of orators and historians, with a specific emphasis on the critical aspects of the works. Although he didn't request a certain methodical studying of history, he still considered it a potent collection of examples for the writing of a speech. In today's time, when school programs are filled with facts, dates, names, which often render history an unappealing subject for many students, Quintilian's model can be a motivating factor for a different approach to the subject. Quintilian described history as the literary branch closest to poetry, a kind of poetry in prose, written to tell a story, and not prove the truth. In that sense, the Roman author had not distanced himself from the opinion of many of his contemporaries, in that the mission of history was not to question the truth of historical events but to display them artistically. Obviously, historians will not fully agree with this approach, but it should be said that modern literary theory clearly approaches history as a story depicting certain aspects of the past, without the possibility of actually providing an absolute objective truth of past events. Therefore, in order to make studying history interesting to students even today, certain aspects of debate should be included, at least where that is possible, i.e. where it doesn't collide with the aspiration of most to impose their «truth» through the school system.

\section{Oratory in a Foreign Language}

Oratory skill can also serve to help those learning a foreign language. Even in schools conducted in a minority's language, where difficulties regarding mastery of that language are increasingly arising, discussions and preparations in that language can serve their purpose. In such a way, the students are witness to universal and translingual nature of oratory rules. The purpose of this is to generally encourage the students to publically begin speaking in another language. Without using a language, even with a firm grip on grammatical rules, it is impossible to realistically become familiar with a language. Discussions on the relationship to social opportunities, democracy, history and news articles can greatly encourage students to speak in that language, and so realize how the world is in fact a great village. Multilingualism was relevant even in the ancient world. Quintilian, in his thoughts gave an advantage to the Greek writers, and made the Greek language itself within lingual schooling a priority. He firstly claimed that children would learn Latin anyway, as it was the language spoken by their community.

A further reason he prioritized Greek was the complete independence of Latin schools to Greek schools. I prefer that a boy should begin with the Greek language, because he will acquire the Latin in general use, even though we tried to prevent him, and because, at the same time, he ought first to be instructed in Greek learning, from which ours is 
derived. (Quintilian, 1985, 47). From today's viewpoint, we can speak freely of bilingual schooling and of the possibility that two languages and cultures be studied simultaneously without difficulty. Naturally, neither direction should be exaggerated; one should keep to the centre, as Quintilian himself noted: Yet I should not wish this rule to be so superstitiously observed that he should for a long time speak or learn only Greek, as is the custom with most people; for hence arise many faults of pronunciation, which is viciously adapted to foreign sounds, and also of language, in which when Greek idioms have become inherent by constant usage, they keep their place most pertinaciously even when we speak a different tongue. The study of Latin ought, therefore, to follow at no long interval, and soon after to keep pace with the Greek; thus it will happen that when we have begun to attend to both tongues with equal care, neither will impede the other, concluded the Roman author, who thus let us know how, taking into consideration ancient experiences, it is possible to organize schooling in areas of Europe where different languages and cultures mix; this is an expression of a unique civilization area, which draws roots precisely from Greek and Roman legacies.

\section{Conclusion}

In today's democratic conditions, which are related to ancient ones, oratory is an important factor of political life: it is because of this that it can be reinstated to the centre of attention. Unfortunately, schools pay more attention to writing, while the study of speech, or the skill of speech (the term often used is "emotional intelligence") could have positive psychological effects on shy, reserved students. This study remains unimportant, if not completely neglected. The possibilities of using oratory skill in public life could be the bettering of a general social debate or as a tool for promoting truth, or at least persuading someone of the accuracy of one's beliefs. As such, it may once again become an important piece of social as well as political life in a positive sense.

The importance of political speech, in the broadest sense of the term, is identical today as it was during the Greek city-nations. And so, Aristotle's and Quintilian's teaching show us how nothing has really changed significantly throughout the centuries, at least when speaking of the human spirit and basic human skill. If anything has changed, it would be the return of classical ancient Greek and Roman values, which were suppressed during the Middle Ages and later. It can't be a mere coincidence that the term "rhetoric" has both a descriptive and scientific meaning, which relates to both the oldest of communication sciences and the modern popular meaning which follows those methods of communication which are generally regarded as the yield of mystification, manipulation of consciousness and the public, or as a boring and barren means of communication. This ambivalence is the expression of a certain historical development: the one that, between the middle and end of the $19^{\text {th }}$ century practically brought about the removal of rhetoric from the list of the most significant school subjects, as well as its discredit. However, we have recently been witnesses to a reverse process, as rhetoric is once again becoming relevant as a means of expressing argumentation.

As early as ancient times, in the time of the Sophists, there arose the realization of the influence brought about with effective speech, i.e. the possibility and capability to affect an auditorium. It was regarded as an important instrument in the scope of public life, 
especially in politics and the judicial system, as well as in institutions and organizations, private life and interhuman relations. Other than that, we also mustn't forget that ancient Greeks and Romans didn't consider all the negative connotations associated with rhetoric today applicable. Rhetoric, due to its practical meaning within Greek states, and especially in Roman political life, was considered a highly valued literary branch, as well, and so oratory works were viewed as of the highest rank in literature. According to Tacitus, conclusive cause of oratory and literature should not be sought out in moral and educational domains, but in the radical changes of political and social opportunities and relations, that arose after the fall of the Republic. He claims that oratory as one of the means of political expression is firstly subject to the influence of political changes. According to him, it's no so much the disappearance of the Republic, as it is the ceasing of political freedoms and the tsar-like absolutism that are to blame for the oratory's demise. But today, freedom has returned along with democracy, and conditions in which citizens can take their destiny into their own hands have ripened. But this is also something which needs to be learned, from the very start. In general, the danger of seeking out a firm hand to solve problems will always be present ... not just that. Practice has taught us that scholastic responsibilities can contribute to a certain subject, for example literature, becoming uninteresting to the students because precisely because it is presented as mandatory. In this case, it is almost impossible to avoid this problem. Other subjects, ones seemingly less important or newer, such as education for democratic citizenship shouldn't fall victim to the same trap as lovely literature. These subjects should become a «polygon» of novel strategies of learning and teaching, with the goal of developing new skills, which are not in fact new, but a result of an ancient historical school system. Oratory schools and discussions will also become schools teaching of tolerance toward differing opinions. No accumulation of information, no «boring» studying.

To conclude: In a small democratic nation where everything is achieved with words, verbosity becomes both the sword and the shield... a man may use it to say aloud more than with military endeavours. And so, in a nation such as this, nurture of the living word has reached a very high level of development. (Đurić, 1972, 588). However, an unavoidable warning is that words are a powerful weapon, as depicted in a quote by one of the greatest orators of all time, Marcus Tullius Cicero, who says: "My whole care is constantly devoted to this object, to effect, if I can, some good by speaking; but if not, to do at least no harm."

\section{Bibliography}

Aristotle, Poetics, Školska knjiga, Zagreb, 2005.

Aristotle, Rhetoric, Naprijed, Zagreb, 1989.

Cicero, M. T., On the Orator, Matica hrvatska, Zagreb, 2002.

Đurić, M., The History of Hellenic Literature, Belgrade. 1972.

Gottesman, D. - Buzz, M., Masterful Public Speaking, Naklada Jesenski i Turk, Zagreb, 2006.

Plato, Protagoras/Gorgias, Kultura, Belgrade, 1968.

Quintilian, M. F., Education of an Orator, SOUR Veselin Masleša, Sarajevo, 1985.

Winkler M. and Commichau A., Communication and Psychological Rhetoric, Erudita, Zagreb, 2008. 
Žitinski-Šoljić, M., Theory of Communication and Oratory, University of Dubrovnik, Dubrovnik, 2001.

Metodički obzori 6(2011)1

Pregledni rad

UDK: 37:808]"652/20"

Primljeno: 23. 9. 2010.

\title{
DEMOKRATSKO GRAĐANSTVO IZMEĐU SUVREMENE STRATEGIJE UČENJA I ANTIČKOG ISKUSTVA
}

\author{
Dario Saftich, prof. \\ EDIT Rijeka \\ e-mail: dario.saftich@ ri.htnet.hr
}

\section{Sa žetak}

Obrazovanje za demokratsko građanstvo, u uvjetima demokracije, trebalo bi imati sve veću važnost u školskom sustavu. Suvremena strategija učenja i naučavanja ne bi smjela izostaviti antička iskustva i korijene. U demokratskim uvjetima, koji imaju dodirnih točaka s antičkim, govorništvo je važan čimbenik u političkom životu. Upravo stoga se umijeće govora može ponovo vratiti u središte pozornosti. Važnost političkog govora, u najširem smislu riječi, u današnje doba istovjetna je kao u grčkim gradovima-državicama. Aristotelovo i Kvintilijanovo učenje pokazuju da se tijekom stoljeća i tisućljeća u stvari ništa bitno nije promijenilo, barem kad je u pitanju ljudski duh i osnovno čovjekovo umijeće. Moguće je dakle naći poveznicu između obrazovanja za demokratsko građanstvo i retorike, u pozitivnom smislu riječi. Osnovne demokratske vrijednosti i tolerancija mogu se najbolje razvijati diskusijom i uvjeravanjem, ne pukim učenjem formalnih osnova demokratskog uređenja. U radu ćemo ukazati da je strategija učenja, kada se radi o demokratskom građanstvu i o povijesti što je usko povezano, u stvari strategija selekcije, kao u slučaju govorničkog obrazovanja.

Ključne riječi: strategija, obrazovanje, demokracija, demokratsko građanstvo, govorničko umijeće, antičko iskustvo, retorika, selekcija, povijest, tolerancija. 